\title{
RADIOISOTOPE HEPATOGRAPHY IN THE DOG
}

\author{
M. CUPÁK, J. KONRÁD, Eva BURSKÁ and Blanka MARKOVÁ
}

Clinic of Equine and Small Animal Medicine, Faculty of Veterinary Medicine, University of

Veterinary Science, 61242 Brno

\begin{abstract}
Cupák M., J. Konrád, Eva Burská, Blanka Marková: Radioisotope Hepatography in the Dog. Acta vet. Brno, 61, 1992: 115-122.

Radioisotope scanning of the liver chromoexcretion function following the i. $v$. application of ${ }^{131}$ I sulphobromophtalein and investigation of the radioactivity decrease using the external detection over arteria carotis were carried out on 83 dogs. Hepatograms of 45 dogs without clinical signs of hepatopathies and also without deviations from the physiological values of enzyme activity and bilirubin concentration, or without necropsy findings in liver, were evaluated and the basis of $T / 2$ physiological values after the division into vascular (6.3), cellular (8.3) and biliary (10.5) phases and of the physiological value of isotope retention (40.5) were given.

The evaluation of 26 hepatograms obtained from the necropsy examination of the dogs in which various hepatopathies and corresponding pathological deviations in hepatograms had been found indicated also the possibility of a certain categorisation of liver lesions using isotope hepatography.
\end{abstract}

Radioisotope diagnosis, isotope hepatography, ${ }^{131}$ I sulphobromophtalein, hepatogram, dog

The use of radioisotope diagnosis in veterinary medicine has been relatively scarce. At the Clinic of Equine and Small Animal Medicine of the University of Veterinary Science in Brno the radioisotope nephrography (ING) in dogs has been routinely conducted since 1977 . The methods and results obtained in dogs (Štenclová et al. 1973; Procházka, Konrád et al. 1975; Cupák and Nechvátal 1984 and others) and in swine (Cupák and Vorlíček i982) have been published elsewhere. The device for ING has not been employed in other ways although it is convenient also for other radioisotope diagnostic methods, particularly for the radioisotope functional examination of liver (IHG).

In human medicine, radioactive substances were introduced already at the very beginning of the radioisotope scanning methods development (Taplin et al. 1955). The isotope hepatography itself has been described in papers and short communications in specialised journals only.

One of the tasks of polygonal liver cells is to remove some of the products of hemoglobin disintegration from the blood. Similarly, some xenogenous stains are removed following their intravenous application. For radioisotope uses these stains are tagged with a suitable gamma radiator. Their kinetics in an organism can then be examined by a bloodless way using a simple external detection (Bláha 1972). The speed of blood clearance of a xenogenous dye is then an indication of an overall chromoexcretion liver function.

Radioisotope hepatography is a diagnostical method that is relatively rapid, not too laborious, and not too embarrassing for a patient. Compared with the classical liver function tests with non-labelled sulphobromophtalein only a single i. v. puncture is needed both for a possible blood sample taking and for an immediate application of a radioactive preparation. Uthgenant et al. (1966) regard the isotope hepatography as a more sensitive and accurate method. Even a greater resolution power than in case of isotope nephrography has been reported (Strögtes et al. 1973).

Either ${ }^{131}$ I-labelled rose bengal (e. g. Taplin et al. 1955; Winkel 1965 and others) or ${ }^{131}$ I-labelled sulphobromophtalein (e. g. Strögtes et al. 1973; Hengst and Mosler 1973 and other) or possibly other organic dyes labelled with different radioisotopes (Lang 1963) are used in isotope hepatography.

Following the i. v. application of a tagged dye a detector is applied to a place well supplied with blood, e. g. on the head temporal area (Blá ha 1972 and others) and a frequency of gamma-rays in the collimated area is measured. The registering instrument simultaneously records the clearance curve (hepatogram). The curve is then plotted onto a semilogarithmic scale and the speed 


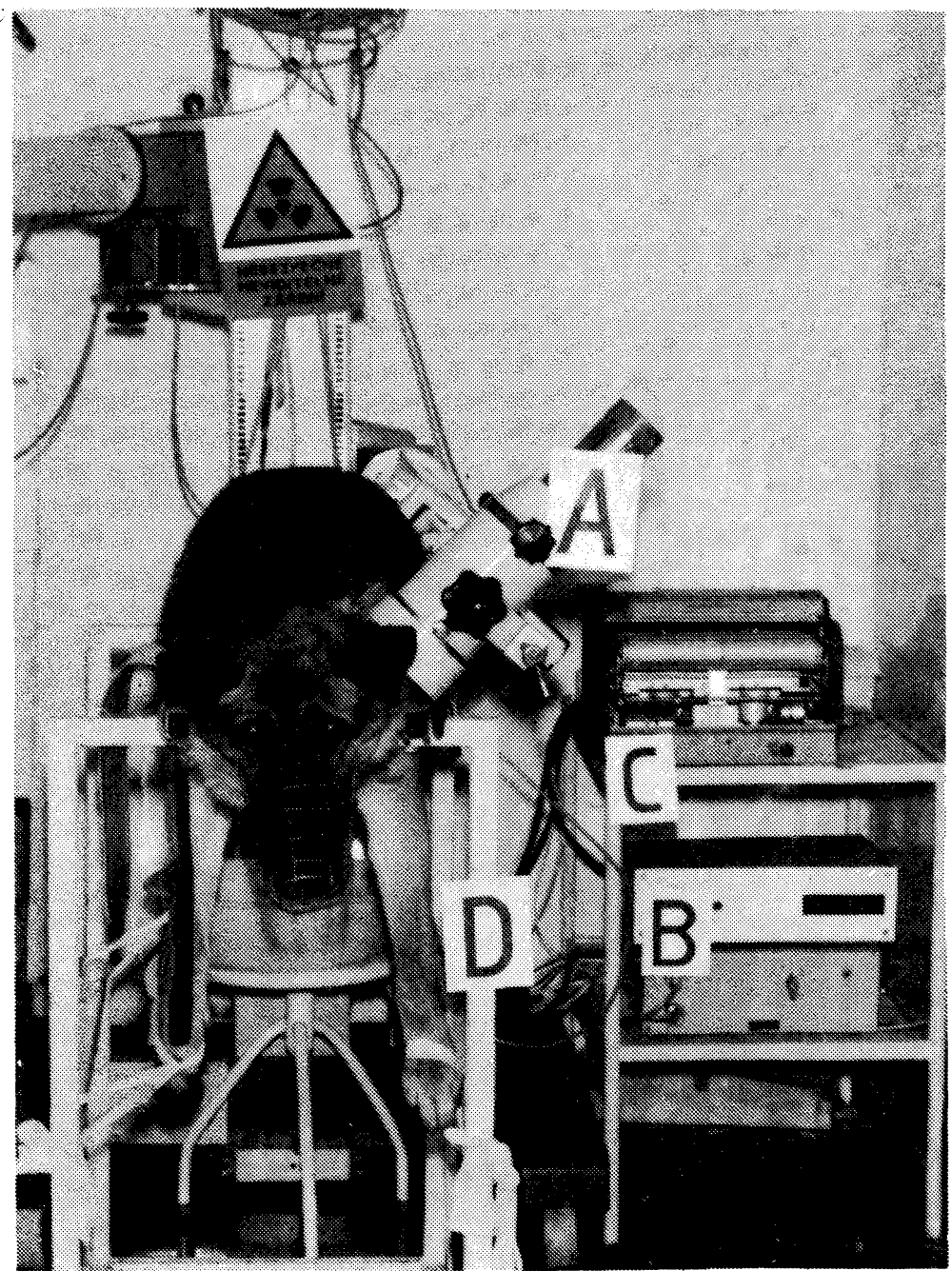

Fig. 1. Apparatus for radioisotope hepatography. A - stand with a collimator and scintillation probe, $\mathrm{B}$ - drive device, $\mathrm{C}$ - recorder, $\mathrm{D}$ - fixation device.

of labelled dye clearance from the blood is evaluated using the determination of $T / 2$ half-life (Bláha 1972). At present, the $T / 2$ value can be obtained by calculating logarithms on a calculator.

The speed of the xenogenous dye clearance from the blood is decreased in all forms of liver dysfunctions, especially in diffuse diseases, and is proportional to the degree of a damage. $\mathrm{T} / 2$ is, however, partially dependent on the methods and radioactive pharmaceuticals used. It is thus necessary for every laboratory to have its own group of experimentally examined subjects (Bláha 1972).

Almost all the authors evaluate the obtained hepatograms in whole after a certain period of time. Only at the Nuclear Medicine Department of the Town Health Centre in Brno (Koudelka and Drášilová 1986) we have encountered the division into vascular, cellular and biliary sections with a calculation of retention percentage. In this laboratory, hepatography is carried out and the results calculated in this way. 
Blahníková and Bláha (1968) when evaluating pathological hepatograms report the highest slow-down of $\mathrm{T} / 2$ in liver lesion with portal hypertension in cirrhoses (by $133 \%$ ), in cardiac congestion in liver (by $41 \%$ ) and the lowest in liver lesion without portal hypertension (by $33 \%$ ). In his earlier work Bláha (1972) reported the lowest slow-down in steatoses (by $20 \%$ ) whereas in chronic hepatopathies it was by $38 \%$, in chronic insufficiencies by $46 \%$, in subacute infectious hepatitis by $60 \%$ and in liver cirrhoses by $70-120 \%$, Strögtes et al. (1973) reported $16 \%$ of abnormal hepatograms but none in cirrhoses and acute hepatitis.

In available literature concerned with veterinary medicine we have not found any report on the application of radioisotope hepatography, not even in the work of Hrušovský and Beneš (1985) on radiology in veterinary medicine. They described isotope nephrography in dogs only and there is only a note on ${ }^{131} \mathrm{I}$ application in the functional tests in liver.

\section{Materials and Methods}

The investigation of chromoexcretion liver function was carried out on a total of 83 dogs of various breeds (and cross-breds), of both sexes, aged 6 months to 16 years and body weight of 7 to $48 \mathrm{~kg}$. In this experiment, experimental dogs, patients with various diagnoses, and 30 dogs assigned for euthanasia from various reasons were used.

The experiment was conducted on a device for radioisotope diagnosis used in human medicine employed so far at our clinic for isotope nephrography oniy. This equipment comprises a NED 902 stand with a scintillation probe (NKG 322 A detection unit) and a round collimator with a $100 \mathrm{~mm}$ diameter, all made by Tesla (Fig. 1,A), a drive conversion device (Fig. 1,B), a recti-riter Texas Instruments Inc. register (Fig. 1,C) and a fixation device developed at the Radioisotope Laboratory of the University (Fig. 1,D).

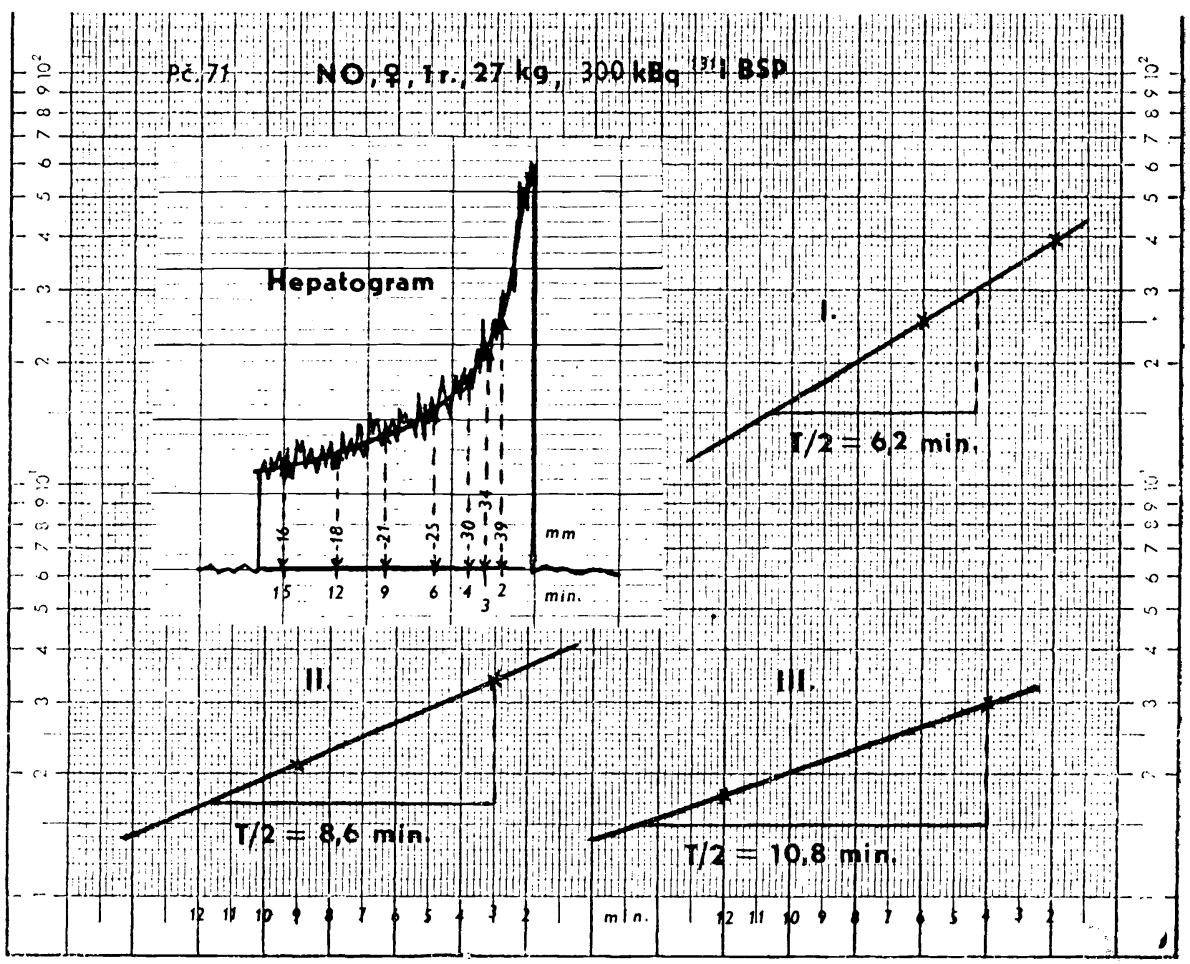

Fig. 2. Hepatogram and its evaluation by plotting on a semilogarithmic paper. 
Prior to the examination, blood samples were taken from the dogs to determine the enzyme activity using the Biolatest and the bilirubin concentration using the Jendrassik-Graf method. This was carried out in the laboratories of the Internal Clinics of the University.

The dogs were fixed and a collimator was attached from the left to the lower half of the neck, close to the shoulder joint, so that the detection probe could approach a. carotis (Fig. A). ${ }^{131}$ I sulphobromophtalein was applied i. v. into v. cephalica antebrachii or into v. saphena in the dose of $11.1 \mathrm{kBq}$ per $1 \mathrm{~kg}$ body weight. The chromoexcretion function was registered for the period of 15 minutes and a hepatogram was recorded.

Dogs assigned to euthanasia were killed immediately after the cessation of hepatographic recording using an i. v. application of Thiopental. Necropsy examination was carried out at the Department of Pathological Morphology of the University.

The evaluation of hepatograms was based on the curve height in $\mathrm{mm}$ from the zero basis (background) in the 2nd, 3rd, 4th, 6th, 9th, 12th, and 15th minute by the division of the curve into three phases: vascular (from 2nd to 6th minute), cellular (from 3rd to 9th minute) and biliary (from 4th to 12 th minute). To determine the $\mathrm{T} / 2$ half-life the results were plotted on a semilogarithmic paper (Fig. 2), later it was calculated using an equation:

$$
\mathrm{T} / 2=\frac{\ln 2 \times(\mathrm{t} 2-\mathrm{t} 1)}{\ln 1 \text { st value }-\ln 2 \text { nd value }}
$$

where $\mathrm{t} 1$ and $\mathrm{t} 2$ stand for the first and second investigation times, resp. For individual phases the numerator is constant: vascular ( 6 minus 2 minutes) $=2.772$, cellular ( 9 minus 3 minutes) $=$ $=4.158$, biliary $(12$ minus 4 minutes $)=5.544$. Denominator verbally: logarithm of the millimeter value in the first measured time minus logarithm of the millimeter value in the second measured time.

The retention is a percentage expression of the ratio of the curve height in $\mathrm{mm}$ at the 15 th minute and of the curve height in $\mathrm{mm}$ at the $2 \mathrm{nd}$ minute of the test. It denotes a percentage of a radioactive preparation still remaining in the blood circulation.

The resulting values were statistically evaluated on a Hewlett-Packard Model 10 calculator at the Data Processing Laboratory of the Clinics of Internal Diseases of the University. Means and standard deviations were determined.

\section{Results}

Out of the total number of 83 examined dogs 45 animals were either without clinical signs of a disease or the signs were not too serious, e. g. without even suspect hepatopathy or circulatory system disturbances. These dogs did not show pathological deviations both in enzyme activity and bilirubin concentration. Four dogs, in which no changes in liver were found by necropsy examination, were included into the latter. Physiological liver function can thus be expected in this group of 45 dogs. The calculated results of isotope hepatography yielded the following mean values of $\mathrm{T} / 2$ : vascular phase $6.3(\mathrm{SD} \pm 0.95)$, cellular phase $8.3(\mathrm{SD} \pm 1.10)$ and biliary phase $10.5(\mathrm{SD} \pm 5.50)$. These values represent a basis of physiological values of radioisotope hepatography in the dog.

Thirty dogs underwent necropsy examination and pathological changes found in 26 of them were morphological or also histological and of various kinds and degrees. The deviations found in hepatograms corresponded to these changes and were manifested by various degrees of chromoexcretion delay compared with the physiological values determined by us. In cholecystopathies ( 4 dogs Fig. 3,a), the slow-down of chromoexcretion occurred in the vascular and cellular phases within the range of the standard deviation only, higher delay was observed in the biliary phase. Retention increased to $53 \%$. In steatoses ( 8 dogs - Fig. $3, b)$, the slow-down was observed in all phases with the gradation from the vascular to biliary phase. Retention was $55 \%$. In hepatopathies with chronic venostasis in liver (6 dogs - Fig. 3,c), the total slow-down was found to be even higher, the maximum being at the cellular phase. Retention was as high as $60 \%$. 


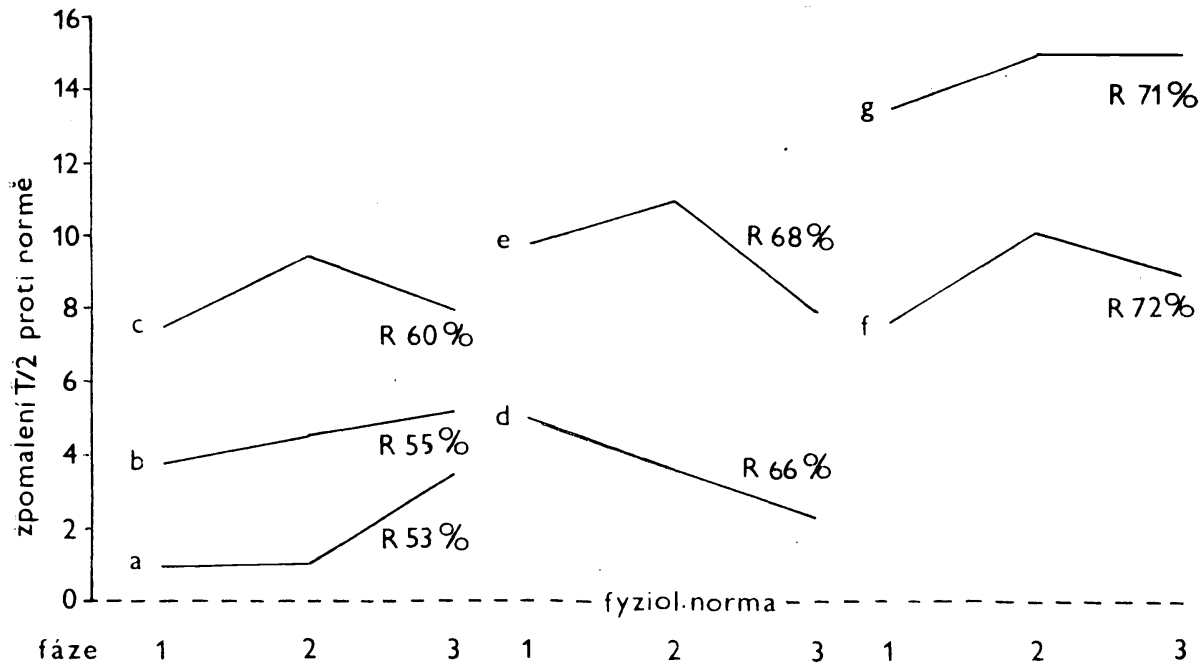

Fig. 3. Course of chromoexcretion slow-down in various liver lesions. a - cholecystopathy, b - steatosis, c - hepatopathy with chronic venostasis, $\mathrm{d}$ - cardiacs with chronic venostasis without hepatopathies, e - cardiacs with chronic venostasis and hepatopathies, $\mathrm{f}$ - hepatopathy with chronic venostasis and cirrhosis, $\mathrm{g}$ - acute hepatitis, $\mathrm{R}=$ retention. $\mathrm{T} / 2$ slow down compared to the physiological value.

In cardiacs with chronic venostasis in liver but without hepatopathies ( 3 dogs Fig. 3,d), the marked slow-down was observed in the vascular phase with a decreasing tendency towards the cellular to biliary phases. Retention was $66 \%$. In cardiac patients with chronic venostasis in liver and hepatopathies (3 dogs Fig. 3,e), the slow-down was even higher, the maximum and minimum being found in the cellular and biliary phases, resp. Retention was $68 \%$. In hepatopathy with chronic venostasis in liver and also with cirrhosis ( 1 dog - Fig. $3, f)$, the delay in the vascular and cellular phases was similar to that of these changes but without cirrhosis, increasing, however, in the biliary phase. The value of retention was the highest found $-72 \%$. The highest slow-down was observed in acute hepatitis ( $1 \mathrm{dog}-$ Fig. $3, \mathrm{~g})$ with the values in the vascular phase only slightly lower than in cellular and biliary phases where these values were identical. Retention was $71 \%$.

Twelve dogs with clinically suspect hepatopathies, cardiopathies, deviations from physiological values of blood biochemical examination and at the same time with hepatograms showing a slow-down when compared with the determined physiological values have not been included into the evaluation. The reason was the impossibility to assess objectively liver changes, particularly with the use of necropsy examination. At this experimental stage we have not considered using the biopsy examination of liver.

\section{Discussion}

Collimation of the scintillation probe on the head (Bláha 1972), particularly at the temporal region (Town Health Centre Brno), cannot be used in the dog since it is impossible to immobilise the dog's head completely without employing 
extreme force. We have, therefore, chosen collimation in the neck region over the arteria carotis that is both well supplied with blood and sufficiently distant from the liver region. Also the immobilisation is easier here. Although many authors, starting from Taplin et al. (1955), have used labelled rose bengal we have selected the ${ }^{131}$ I sulphobromophtalein taking into account a possibility of the mutual exchange of the radiactive pharmaceuticals, of consultations and of the comparison of results with the Nuclear Medicine Department of the Town Health Centre in Brno with which we have established a cooperation. This choice was also based on the fact that different radioactive pharmaceuticals give different results (Bláha 1972).

Bláha (1972) and Winkel (1975) have reported that the speed of the curve decline is reduced in most diffuse liver parenchyma diseases and a change appearing in the affection of the liver parenchyma is difficult to distinguish from the disturbances in the biliary tract flow. In spite of that we have decided to divide the hepatogram into three phases. This approach has been used successfully in practice (Town Health Centre in Brno). The other reason was identical to that in case of the selection of radioactive pharmaceuticals.

The obtained values, suggested as physiological, differ from those found in the Town Health Centre in Brno (4.5 - SD $\pm 0.5 ; 6.0-S D \pm 0.5 ; 9-S D \pm$ \pm 1.0 ; retention $28-30 \%$ ). The values and standard deviations found by us. are higher. This is undoubtedly caused by the differences in the methods used (Bláha 1972), in our case by the localisation of the collimator. Whereas in case of an adult man the diagonal distance of the examined temporal region from the liver is about $60 \mathrm{~cm}$ the distance between the dog neck and liver is in every case smaller. Since this distance decreases with the decreasing size of a dog a partial diffusion of the declining radioactivity at the spot of collimation with increasing radioactivity in the liver region cannot be excluded. Thus a higher standard deviation is seen since at a relatively broad body weight range the obtained minimum and maximum values were different. Even a co-effect of the collimator of unsuitable size with too broad a take cannot be excluded. We have not pursed a potential categorisation of values according to body weights of dogs.

The values obtained from pathological hepatograms are similar to those found by Blahníková and Bláha $(1968 ; 1972)$ in that steatoses show the lowest slow-down whereas the highest slow-down was observed in liver lesions with portal tension as in case of cirrhoses and cardiopathies together with hepatopathies and chronic venostasis. Similar results were observed at the Town Health Centre in Brno, the exception being that these authors found the highest slow-down in cirrhoses and not in acute hepatitis. In our case we observed acute hepatitis only once, that is without a possibility of averaging, and the result can thus be quite incidental.

\section{Conclusion}

The aim of the present work was to verify a possibility of radioisotope hepatography applications in dogs. The utilisation and suitability of this method, that is used as a supplementary way of diagnosing hepatopathies in dogs, have been demonstrated. Forty-five healthy dogs were examined and based on the results physiological values of hepatograms that were divided into vascular (6.3), cellular (8.3) and biliary (10.5) phases were determined. Physiological values of isotope retention (40.5) were also established. 
The evaluation of hepatograms of 26 dogs in which deviations from physiological values and findings of various hepatopathies were observed at subsequent necropsy examination has also suggested a possibility of a certain categorisation of liver lesions using radioisotope hepatography.

\section{Radioizotopová hepatografie u psů}

U 83 psů bylo provedeno radioizotopové vyšetření chromoexkreční funkce jater po i. v. aplikaci ${ }^{131} \mathrm{~J}$ bromsulfanu a sledování poklesu radioaktivity zevní detekcí nad arteria carotis. Vyhodnocením hepatogramu 45 psů bez klinických příznaků hepatopatií a také bez odchylek od fyziologických hodnot enzymatické aktivity a hladiny bilirubinu, event. bez nekroptických nálezů na játrech, byl stanoven základ fyziologických norem $\mathrm{T} / 2$ po rozložení hepatogramu do fází. vaskulární, celulární a biliární.

Hodnocení hepatogramů $26 \mathrm{z}$ nekropticky vyšetřených psů, u nichž byly zjištěny rưzné hepatopatie a odpovídaiící patologické odchylky $\mathrm{v}$ hepatogramu, naznačilo i možnost určité kategorizace jaterních lézí izotopovou hepatografí.

\section{Радиоизотопная гепатография собак}

На 83 собаках проводили радиоизотопные исследованиа хромовыделяющей функции печени после внутривенного введения 131 Ј бромсульфана, а также наблюдения за понижением радиоактивности наружным определением над arteria carotis. Оценку гепатограммы 45 coбак без клинических признаков гепатопатии и без отклонений физиологических величин энзиматической активности и концентрации билирубина или без некроптических явлений на печени, проводили на основе определения основы физиологических величин Т/2 после распределения гепатограммы на васкулярные $(6,3)$, целлюлярные $(8,3)$ и билиарные $(10,5)$ фазы, а также основы физиологической величины. задержки изотопа $(40,5)$.

Оценка гепатограмм 26 из некроптически исследуемых собак, отличающихся разными гепатопатиями и соответствующими патологическими отклонениями гепатограммы, подсказала также возможнось проведения определенной категоризации повреждений печени с помощью изотопной гепатографии.

\section{References}

BLÁHA, V.: Izotopové vyšetřeni jater. Čas. Lék. českých, 111, 1972: 73-78

BLÁHA, V.-HORÁK, J.-KOLfNSKÁ, J.: Možnosti a meze informací při funkčním izotopovém vyšetření jater. Prakt. Lékař, 65, 1985: 573-574

BLAHNIKOVÁ, L.-BLAHA, V.: Klinický význam současného vyšetření únikových křivek ${ }^{198} \mathrm{Au}$ a bengálské červeně ${ }^{131} \mathrm{~J}$. Čas. Lék. českých, 107, 1968: 409-411

BEINING, H.-STRUBELT, O. - WUUST, H.-HELPAP, B.: Über den Einfluss experimenteller Lebervenenstauung auf die ${ }^{131} \mathrm{~J}$ Bengalrot-Probe, die Serumtransaminasen und das histologische Bild der Leber. Z. Gastroenterol., 5, 1967: 20-25

CUPÁK, M. - NECHVÁTAL, M.: Die Anwendung der Isotopennephrographie vor der Nephrektomie beim Hund. Mh. Vet.-Med. (Leipzig), 39, 1984: 259-261 
"CUPÁK, M.-VORLfČEK, J.: Izotopová nefrografie při sledování nefrotoxicity cisplatiny u prasat. Veter. Med. (Praha), 27, 1982: 541-550

HENGST, W.-MOSLER, D.: Kritische Untersuchungen zum Leberfunktiontest mit ${ }^{131} \mathrm{~J}$ Bromsulfan und Bromsulphtalein. Fortschr. Röntgenstr. Nuklearmed., 118, 1973: 330-335

HRUŠOVSKÝ, J.-BENES, J.: Radiologie ve veterinárním lékařství. Naše vojsko, Praha, 1985, 238

PROCHÁZKA, Z. - KONRÁD, J. et al.: Využití radioizotopů v klinické diagnostice vnitřních chorob psů. Project report VL-2-4-17, VŠV, Brno, 1975, 82

ROSENTHALL, L. - ARZOUMANIAN, A.-LISBONA, R.: The use of combined ${ }^{131} \mathrm{~J}$ Rose Bengal and Bromsulfalein as a test of liver function. J. Can. Ass. Radiol., 23, 1972: 245-248

SKAUNIC, V. - HŮLEK, P.: Fyziologické podklady pro kvantitativní hodnocení jaterní chromoexkrece. Prakt. Lékař, 65, 1985: 565-568

STRÖGTES, M. W.-NEHEN, H. G.-HEISSEN, E.: Leberfunktions-Untersuchungen mit ${ }^{131}$ J-Bromsulfalein. Z. Leber-Magen-Darm, 3, 1973: 257-260

ŠTENCLOVÁ, D. - PROCHÁZKA, Z. - KONRÁD, J.: Využití izotopové nefrografie při funkčním vyšetření ledvin psů. Veter. Med. (Praha), 18, 1973: 585-592

TAPLIN, G. V.-MEREDITH, O. M. J.-KADE, H.: The radioactive (131 J-tagged) Rose Bengal uptake-excretion test for liver function using external gamma ray scintillation couting techniques. J. Lab. clin. Med., 45, 1955: 665

UTHGENANNT, H.-DAHL, P.-PIENING, O.: Vergleichende Untersuchungen mit dem Radio-Bengalrosa und dem Bromsulphalein Test. Dtsch. med. Wschr., 91, 1966: $211-216$

WINKEL, Z. K.: Nuklearmedizin. Springer Verlag, Berlin-Heidelberg-New York, 1975, 245 